\title{
Tuberculosis is associated with non-tuberculosis-related deaths among HIV/AIDS patients in Rio de Janeiro
}

\author{
A. G. Pacheco, ${ }^{*}$ V. G. Veloso, ${ }^{\dagger}$ E. P. Nunes, ${ }^{\dagger}$ S. Ribeiro, ${ }^{\dagger}$ M. R. C. Guimarães, ${ }^{\dagger}$ M. C. Lourenço, ${ }^{\dagger}$ \\ F. C. Q. Mello, ${ }^{\ddagger}$ B. Grinsztejn ${ }^{\dagger}$
}

*Programa de Computação Científica, Fundação Oswaldo Cruz, Rio de Janeiro, 'Instituto de Pesquisa Clínica Evandro Chagas, Fundação Oswaldo Cruz, Rio de Janeiro, 'Instituto de Doenças do Tórax, Universidade Federal do Rio de Janeiro, Rio de Janeiro, Rio de Janeiro, Brazil

S U M M A R Y

SETTING: Human immunodeficiency virus (HIV) infected patients followed in a large cohort in Rio de Janeiro, Brazil.

OB JECTIVE: To evaluate the association of tuberculosis (TB) and other covariables with non-TB-related (NTR) causes of death (CODs).

DESIGN : Patients aged $>18$ years were followed from 1997 to 2009, until death or 31 December 2009, whichever was earlier. CODs were ascertained using a standardised algorithm. TB diagnosis and prophylaxis followed Brazilian guidelines. Poisson models were used to calculate adjusted rate ratios (aRRs).

RESULTS: Of 2887 patients included in the study, 761 had TB $(26.4 \%)$. NTR death rates were twice as high among patients with TB (4/100 vs. 2.09/100 patientyears). TB was associated with NTR deaths (aRR 1.4,
95\%CI 1.05-1.86, $P=0.01)$. Highly active antiretroviral treatment (HAART) was protective against NTR (aRR 0.46, 95\%CI 0.34-0.61, $P<0.001$ ). Among patients who had never had active TB, prophylaxis was also protective against NTR (aRR $0.45, P=0.04)$. The CD4 cell count increase was very modest for both TB and NTR CODs compared to those who did not die (0 vs. 249 cells, $P<0.001$ ).

CONCLUSIONS: TB was significantly associated with increased NTR CODs, indicating rapid progression of disease and increased long-term risk of mortality, probably related to persistent immunodeficiency or incomplete immune recovery. Our results confirm the benefits of HAART and TB prophylaxis.

KEY WORDS : cohort; antiretroviral therapy; mortality
THERE HAS BEEN a significant decrease in tuberculosis (TB) incidence rates in the highly active antiretroviral treatment (HAART) era among human immunodeficiency virus (HIV) infected patients worldwide and in Brazil in particular. ${ }^{1}$ TB still poses a great burden among HIV-infected patients, particularly in high TB prevalence settings. In Brazil, incidence estimates for TB all forms was about 80 per 100000 population in 1990 and had fallen to 50/ 100000 by $2010 .^{1}$ In Rio de Janeiro State, the incidence rate among confirmed cases has been consistently higher than national numbers, decreasing from $115 / 100000$ in 2001 to $89 / 100000$ in $2009 .^{2}$ Some regions of Rio de Janeiro City (RJC) have very high incidence rates, of $>550 / 100000 .^{3}$

The acquired immune-deficiency syndrome (AIDS) incidence rate in Brazil increased from 15.8/100 000 in 1997 to about 20/100000 in 2009. 2 In RJC, between 1995 and 2004 both TB and AIDS notifications decreased in the city, while TB-HIV coinfection was $15 \%$ in the first year of AIDS diagnosis. ${ }^{4}$
Although mortality due to AIDS has been stable in Brazil over the last decade, Rio de Janeiro State has the second highest mortality in the country, at 9.1/ $100000 .^{5}$

Although the proportion of $\mathrm{TB}$ deaths among individuals without HIV or AIDS mentioned in their death certificate decreased in Brazil from 1999 to 2011, this proportion has remained approximately the same among those with HIV/AIDS mentioned, indicating the important role of $\mathrm{TB}$ on HIV/AIDS mortality in the country. ${ }^{6}$ Among HIV-infected patients, TB incidence rates ranging between 1.10 and 1.31/100 person-years (py) have recently been reported in RJC. ${ }^{7}$ The same study reported that after health professionals had been trained in Brazilian guidelines, which recommend 6-month isoniazid preventive therapy (IPT) for eligible patients, there was a significant increase in screening rates for latent tuberculous infection (LTBI) and use of IPT. In a substudy conducted between September 2003 and September 2005 , only $45 \%$ of eligible patients

Correspondence to: Antonio Guilherme Pacheco; PROCC - FIOCRUZ, Av Brasil 4365, Manguinhos 21045-360, Rio de Janeiro, RJ, Brazil. Tel: (+55) 213836 1100. Fax: (+55) 212270 5141. e-mail: apacheco@fiocruz.br Article submitted 3 March 2014. Final version accepted 18 July 2014. 
underwent a tuberculin skin test and only $11 \%$ ever started IPT. ${ }^{8}$

High mortality has been reported among HIVinfected patients treated for active TB. ${ }^{9,10}$ Deaths among these patients may have a number of causes, depending on the degree of immunosuppression and the availability of adequate anti-tuberculosis treatment and antiretroviral therapy (ART). While TB may directly contribute to mortality, and remains a major cause of death among these patients, ${ }^{11}$ other opportunistic and non-opportunistic infections and comorbidities may play an important role in those who receive appropriate anti-tuberculosis treatment. ${ }^{12-14}$

The proportion of non-AIDS-related causes of death (CODs) has been increasing in the HAART era, as demonstrated in Brazil ${ }^{15}$ and in two different HIV-infected cohorts in Rio de Janeiro. ${ }^{16,17}$ This change was chiefly driven by a marked decrease in AIDS-related CODs, while the incidence of nonAIDS-related CODs remained relatively stable.

These figures reveal that TB is still a major public health problem for the population in general, and in particular for HIV-infected patients living in Rio de Janeiro. TB greatly increases the risk for all-cause mortality in HIV-infected patients, ${ }^{18}$ but little is known about non-TB-related (NTR) CODs. Moreover, some studies highlight $\mathrm{TB}$ as an independent risk factor for mortality by other causes, as shown in the case of mortality due to lung cancer among elderly patients in Hong Kong, for example. ${ }^{19}$

In the present study, we evaluated the association of TB and other covariables with NTR CODs in a cohort of HIV-infected patients in Rio de Janeiro, Brazil.

\section{STUDY POPULATION AND METHODS}

The study was conducted at the Evandro Chagas Clinical Research Institute, Oswaldo Cruz Foundation (IPEC/FIOCRUZ), one of the largest infectious disease research centres in Brazil, which has provided HIV/AIDS care since 1986. An observational, longitudinal, clinical database is maintained on patients receiving primary and specialised out- and in-patient HIV care at the institution. Details of the HIV/AIDS clinical cohort have been published elsewhere. ${ }^{16,20}$ Patients aged $>18$ years who were followed from 1997 to 2009, until death or 31 December 2009, whichever was earlier, were included in the study. Active review of death certificates in State-wide databases was routinely performed for all patients with a previously validated linkage algorithm. ${ }^{21}$ CODs were then ascertained using the CoDe algorithm (http://www.cphiv.dk/CoDe/). NTR CODs were defined as the absence of any mention of TB in the CoDe review form.

TB was diagnosed per Brazilian guidelines and was considered as the first occurrence noted on the medical chart. Study participants were divided into three groups according to time of $\mathrm{TB}$ diagnosis: previous TB (PreTB), concurrent TB (CurTB) and prospective TB (ProTB), defined as having the date of first TB diagnosis $<60$ days from start of follow-up, within a 60-day window around follow-up and $>60$ days after start of follow-up, respectively.

Variables considered were included in the models either as time-updated variables such as calendar year, HAART use, TB prophylaxis and CD4 cell count; or fixed variables, such as TB category, sex, age at entry and level of education. In time-updated variables, the py contribution was divided according to the category of the individual at a certain point in time until that category changed. For example, a patient who was not on HAART but then started on HAART was classified under the non-HAART category until the date HAART was started, after which the patient was included in the HAART use category.

Descriptive statistics comparing outcomes were tested using $\chi^{2}$, Wilcoxon or Kruskal-Wallis tests, depending on the nature of the comparison; $95 \%$ confidence intervals (CIs) for rates were calculated based on Poisson distributions. Poisson models were used to calculate rate ratios (RRs), with robust variances. All analyses were performed in $\mathrm{R}$ for Windows 3.0.1.22

The study was approved by the Instituto de Pesquisa Clínica Evandro Chagas Ethics Committee, Rio de Janeiro, RJ, Brazil (CAAE 0032.0.009.00010).

\section{RESULTS}

Of the 2887 patients included in the study, 761 had TB $(26.4 \%)$. Of these, respectively 202 (26.5\%), 384 (50.5\%) and 175 (23\%) were PreTB, CurTB and ProTB. The overall rate of PreTB was 1.64 cases $/ 100$ py. There were 423 deaths, at a mortality rate of 3.4/ 100 py. Sixteen cases were not classified by the CoDe algorithm; however, the characteristics of these patients were similar to those of classified cases (data not shown). Among the 407 classified cases, 72.6\% were NTR deaths. Death rates for all three TB categories were $4 / 100$ py $(3.76,95 \%$ CI $2.61-5.26$; 4.02, 95\% CI 2.95-5.34; and 4.11, 95\% CI 2.63-6.11 for PreTB, CurTB and ProTB, respectively) and 2.09/ 100 py (95\% CI 1.81-2.40) among those who did not have TB.

Table 1 shows specific underlying CODs among individuals who had TB and died due to an NTR COD. The great majority were AIDS-related $(73.3 \%)$, while $10.5 \%$ were non-AIDS-related infectious diseases (sepsis and other infections). Of the remaining $16.2 \%$ of non-AIDS-related non-infectious disease, about two thirds were attributed to renal 
Table 1 Underlying causes of death for patients with TB who died of non-TB-related CODs

\begin{tabular}{lc}
\hline COD & $n(\%)$ \\
\hline AIDS-related & $77(73,3)$ \\
Infection & $39(37.1)$ \\
Neoplasia & $13(12.4)$ \\
Unspecified & $25(23.8)$ \\
Non-AIDS-related & $28(26.7)$ \\
Sepsis & $6(5.7)$ \\
Infection & $5(4.8)$ \\
Renal & $4(3.8)$ \\
Intoxication & $4(3.8)$ \\
Unknown & $3(2.9)$ \\
Violent & $3(2.9)$ \\
Other & $3(2.9)$ \\
Total & $105(100)$ \\
\hline
\end{tabular}

$\mathrm{TB}=$ tuberculosis; $\mathrm{COD}=$ cause of death; $\mathrm{AIDS}=$ acquired immune-deficiency syndrome.

failure, acute intoxication and violent causes other than suicide. Overall, $90 \%$ of NTR deaths could be attributed to some degree of immunodeficiency according to a specific CoDe definition.

Table 2 shows descriptive statistics comparing covariables among those who had non-TB-related CODs, those who had TB-related CODs and those who were alive at the end of the study. All variables were significantly different between the groups, except sex. Those who did not die were younger, more educated and had higher CD4 counts compared to the other two groups. They also had a higher proportion of patients who were ever on HAART and who underwent TB prophylaxis compared with the other two groups. However, when we compared only non-TB-related with TB-related groups, none of those differed except for TB category.

Previous, concurrent and prospective TB were all significantly associated with risk for NTR CODs, with crude RRs (cRRs) of respectively 1.82, 1.84 and 2.00 (all $P<0.001$ ). The overall cRR of all forms of TB taken together was $1.87(P<0.001)$. Table 3 shows the final model with all covariables included. The adjusted RRs for the three TB categories were weaker, but still significant. Higher CD4 counts, higher education, HAART use and TB prophylaxis were all strongly protective, while older age and male sex were associated with risk for NTR CODs. When we combined all TB categories (not shown in table), the association remained significant after controlling for all covariables (aRR 1.4, P=0.01).

Subset analysis among only those patients who did not have active TB showed that TB prophylaxis was still strongly protective after controlling for covariables (aRR $0.45, P=0.04$ ), indicating that protection may also be associated with LTBI.

Table 4 shows time (in weeks) from TB to death or end of follow-up, from HAART initiation to death or end of follow-up, and from HAART initiation to TB diagnosis, comparing those who died with TB-related CODs, NTR CODs and those still alive at the end of follow-up. Patients who died due to TB-related causes tended to start HAART later than the other groups relative to TB diagnosis (median of 5.9 weeks after TB diagnosis), while the other two groups started before TB diagnosis and had relatively long intervals

Table 2 Descriptive statistics for the variables studied comparing three possible outcomes: non-TB-related causes of death, TBrelated causes of deaths and alive at end of follow-up*

\begin{tabular}{|c|c|c|c|c|}
\hline & $\begin{array}{c}\text { Non-TB-related deaths } \\
n(\%)\end{array}$ & $\begin{array}{c}\text { TB-related deaths } \\
n(\%)\end{array}$ & $\begin{array}{l}\text { Alive } \\
n(\%)\end{array}$ & $P$ value \\
\hline Total & 307 & 100 & 2464 & \\
\hline $\begin{array}{l}\text { Sex, \% } \\
\text { Female } \\
\text { Male }\end{array}$ & $\begin{array}{l}103(33.6) \\
204(66.4)\end{array}$ & $\begin{array}{l}36(36) \\
64(64)\end{array}$ & $\begin{array}{r}876(35.6) \\
1588(64.4)\end{array}$ & 0.78 \\
\hline Age, years, median [IQR] & $38[30.3-45.6]$ & $37.7[29.8-45.8]$ & $35.4[28.5-42.4]$ & $<0.001$ \\
\hline $\begin{array}{l}\text { Education, } \% \\
\text { Up to } 5^{\text {th }} \text { grade } \\
6^{\text {th }} \text { to } 9^{\text {th }} \text { grade } \\
>9^{\text {th }} \text { grade }\end{array}$ & $\begin{array}{r}112(37.1) \\
95(31.5) \\
95(31.5)\end{array}$ & $\begin{array}{l}43(44.3) \\
29(29.9) \\
25(25.8)\end{array}$ & $\begin{aligned} 652 & (26.5) \\
576 & (23.5) \\
1228 & (50)\end{aligned}$ & $<0.001$ \\
\hline Baseline CD4 count, cells/mm³ , median [IQR] & $138[31-327]$ & $73[41-188]$ & $313[135.8-520]$ & $<0.001$ \\
\hline $\begin{array}{l}\text { Ever been on HAART } \\
\text { No } \\
\text { Yes }\end{array}$ & $\begin{array}{r}85(27.7) \\
222(72.3)\end{array}$ & $\begin{array}{l}36(36) \\
64(64)\end{array}$ & $\begin{array}{r}536(21.8) \\
1928(78.2)\end{array}$ & $<0.001$ \\
\hline $\begin{array}{l}\text { TB prophylaxis } \\
\text { No } \\
\text { Yes }\end{array}$ & $\begin{array}{c}299(97.4) \\
8(2.6)\end{array}$ & $\begin{array}{c}95(95) \\
5(5)\end{array}$ & $\begin{array}{r}2232(90.6) \\
232(9.4)\end{array}$ & $<0.001$ \\
\hline $\begin{array}{l}\text { TB category* } \\
\text { No TB } \\
\text { Previous TB } \\
\text { Concurrent TB } \\
\text { Prospective TB }\end{array}$ & $\begin{aligned} 202 & (65.8) \\
34 & (11.1) \\
47 & (15.3) \\
24 & (7.8)\end{aligned}$ & $\begin{array}{c}0(0) \\
11(11) \\
52(52) \\
37(37)\end{array}$ & $\begin{array}{l}1911(77.6) \\
156(6.3) \\
284(11.5) \\
113(4.6)\end{array}$ & $<0.001$ \\
\hline
\end{tabular}

\footnotetext{
${ }^{*} \chi^{2}$ and Wilcoxon tests were used for categorical and continuous variables, respectively.
}

$\mathrm{TB}=$ tuberculosis; IQR = interquartile range; HAART = highly active antiretroviral treatment. 
Table 3 aRRs, 95\%Cls and $P$ values calculated using Poisson models for variables and non-TB-related mortality

\begin{tabular}{lcr}
\hline Variables* & aRR $(95 \% \mathrm{Cl})$ & Robust $95 \% \mathrm{Cl}$ \\
\hline No TB & & Reference \\
Previous TB & $1.28(0.88-1.88)$ & $0.88-1.88$ \\
Current TB & $1.35(0.96-1.91)$ & $0.91-2.01$ \\
Prospective TB & $1.71(1.1-2.64)$ & $1.1-2.65$ \\
CD4 $\leqslant 100$ & & Reference \\
CD4 $>100$ & $0.33(0.24-0.46)$ & $0.23-0.47$ \\
CD4 missing & $0.12(0.09-0.16)$ & $0.09-0.16$ \\
TB prophylaxis & $0.41(0.19-0.88)$ & $0.2-0.86$ \\
HAART & $0.46(0.35-0.59)$ & $0.34-0.61$ \\
Age $>40$, years & $1.73(1.37-2.19)$ & $1.35-2.22$ \\
Male sex & $1.46(1.14-1.88)$ & $1.12-1.9$ \\
$>9$ th grade education & $0.56(0.44-0.72)$ & $0.43-0.74$ \\
\hline
\end{tabular}

* All values are adjusted for calendar year.

aRR = adjusted rate ratio; $\mathrm{Cl}=$ confidence interval; $\mathrm{TB}=$ tuberculosis; HAART = highly active antiretroviral therapy.

between HAART initiation and death (interquartile range [IQR] 12.5-231.5 weeks), with shorter intervals between TB diagnosis and death. Patients who died due to NTR CODs started HAART at time points between those alive and those who died due to $\mathrm{TB}$, but had longer TB to death intervals on average. However, these time intervals varied widely: $25 \%$ of the patients died within $<14$ weeks, while $25 \%$ died $>5$ years after TB diagnosis. These findings suggest that patients who died from TB-related CODs were diagnosed with TB during HAART, but once they had TB they were prone to die within a short period of time, with TB acting as a short-term marker. Among those who died due to NTR CODs, TB acted as both short- and long-term marker for NTR CODs.

With regard to CD4 count, we examined the difference between CD4 counts closest to death or end of follow-up and those closest to TB diagnosis. Patients who survived had a median recovery of 249 cells $/ \mathrm{mm}^{3}$ (IQR 86.8-448), while those with TBrelated and NTR CODs had a median of 0 cells $/ \mathrm{mm}^{3}$ (IQRs 0-7.5 and -0.8-22.2, respectively; $P<0.001$ ). Those who were alive for over a year after $\mathrm{TB}$ diagnosis had a median recovery of 303 cells $/ / \mathrm{mm}^{3}$ (IQR 112-496), while those with NTR CODs had a median recovery of only 18 cells $/ \mathrm{mm}^{3}$ (IQR $-43.5-$ 144.5; $P<0.001)$.

\section{DISCUSSION}

In this study $\mathrm{TB}$ was significantly associated with increased NTR deaths in HIV-infected individuals in
Rio de Janeiro, Brazil. To our knowledge, this is the first study to report these findings: all causes of death after a TB episode were evaluated, allowing us to distinguish between TB-related and NTR CODs among HIV-infected patients in a high TB burden setting with free access to HAART. Both overall and TB categories had significant adjusted risk ratios, indicating an increase of $40 \%$ in the risk of NTR CODs among patients diagnosed with active TB at any time point after HIV diagnosis.

Our results show the benefits of HAART and TB prophylaxis, as both were strongly protective against NTR CODs, in line with recently published data for overall mortality in Rio de Janeiro. ${ }^{7}$ This is yet another reason why clinicians should follow established ART and IPT guidelines.

Indications for HAART in Brazil follow national guidelines on HIV, ${ }^{23}$ which were developed by a panel of external advisors and are reviewed on a regular basis. These guidelines are applied across the country. Over the years, the Brazilian national guidelines have changed following major advances in the field. In the last 5 years, the CD4 threshold at which treatment is initiated has moved upwards, from 350 to 500 cells $/ \mathrm{mm}^{3}$; for patients with symptoms, serodiscordant couples and pregnant women, HAART is recommended irrespective of CD 4 count. As of 1 December 2013, the national guidelines recommend the test and treat approach whereby HAART is recommended for all HIVpositive patients, regardless of CD4 cell count. In addition to efavirenz-based first-line treatment, the

Table 4 Time in weeks from event to death or end of follow-up or TB*

\begin{tabular}{|c|c|c|c|c|}
\hline Time period & $\begin{array}{c}\text { Alive } \\
(n=553) \\
\text { Median [IQR] }\end{array}$ & $\begin{array}{c}\text { TB deaths } \\
(n=100) \\
\text { Median }[\mathrm{IQR}]\end{array}$ & $\begin{array}{c}\text { Non-TB-related deaths } \\
(n=105) \\
\text { Median [IQR] }\end{array}$ & $P$ value \\
\hline TB to death or end of follow-up & $242.1[94.3-428.1)$ & $6.1[0.7-38.1]$ & 85.9 [14.4-257.3] & $<0.001$ \\
\hline HAART to death or end of follow-up & $256.4[91.4-452.9]$ & $89.1[12.5-231.5]$ & $192.9[51.3-368.6]$ & $<0.001$ \\
\hline HAART to TB & $-5.4[-23.6$ to 2.3$]$ & $5.9[-5.3$ to 152.8$]$ & $-2.1[-22.4$ to 48.9$]$ & $<0.001$ \\
\hline
\end{tabular}

* Wilcoxon tests were used for comparisons (see text for complete explanation)

$\mathrm{TB}=$ tuberculosis; IQR = interquartile range; HAART = highly active antiretroviral therapy. 
Brazilian guidelines recommend second-line protease inhibitor based therapy as well as third-line and salvage therapy, including integrase inhibitors (raltegravir), second generation non-nucleoside reverse-transcriptase inhibitors (etravirine) and darunavir. The application of this specific recommendation is hard to measure, but at least two papers have studied adherence of health professionals to HIV guidelines. ${ }^{8,24}$ The results indicate that adherence to HIV guidelines is significantly higher than for TB guidelines, and that they were satisfactorily followed by health care professionals in general.

Other covariables also associated with NTR CODs included higher CD4 counts and higher education as protective factors, and male sex and older age as risk factors. These results are also in agreement with other studies, ${ }^{25-28}$ and our main findings were robust when these variables were controlled for.

Although about $16 \%$ of NTR deaths were due to non-AIDS-related non-infectious diseases, the great majority of those deaths $(90 \%)$ can be attributed to immunodeficiency-related CODs. This finding is also in agreement with other previous reports that showed that although there has been a significant decrease in AIDS-related CODs, infectious diseases still account for the majority of CODs among HIV-infected patients. ${ }^{16,17}$

The association of $\mathrm{TB}$ prophylaxis with strong protection against NTR CODs among those who did not have active TB caught our attention, as it may mean that LTBI may also play a role in risk of mortality, as has been suggested with other chronic infections, leading to a sustained inflammatory state that increases the incidence of unfavourable outcomes. The association of IPT with lower early mortality in individuals on ART has already been reported by a South African study. ${ }^{29}$ Our data confirm the positive effects of IPT among AIDS patients.

Our results suggest that TB may be a marker for both short- and long-term sustained immunodeficiency with incomplete immune recovery. In the short term, TB indicates rapid disease progression leading to death either from TB-related or NTR causes, with a substantial proportion of deaths occurring shortly after the TB episode. This may be related to both immune reconstitution and impaired response to the initial HAART regimen.

TB also indicates long-term risk for NTR deaths, as suggested by the incomplete CD4 recovery even among those who survived $>1$ year after TB, leading to NTR deaths in the long term. ART failure may play an important role in this scenario as well. ${ }^{30}$ However, an association of TB with greater mortality and morbidity despite the response to HAART among coinfected patients has already been reported in Kenya, ${ }^{31}$ indicating that in fact $\mathrm{TB}$ should be evaluated as a marker for more rigorous or longerterm monitoring.

Our study has several limitations. First, TB diagnosis followed Brazilian guidelines, which include clinical, non-culture-proven diagnoses. In this cohort specifically, this did not seem to have a major impact; a study with a random sample from the cohort - not necessarily the ones presented hereshowed that two thirds of TB cases were cultureproven (unpublished data).

As TB prophylaxis was analysed as abstracted from medical charts, there is no rigorous control over eligibility, including testing for LTBI and completeness; however, analysis was restricted to those with a valid IPT date. In addition, in the case of TB patients, only those who started IPT before diagnosis were considered. For this group, the median time between IPT and TB was 173.8 weeks (IQR 47.5-274.2).

Adherence to IPT, HAART and anti-tuberculosis treatment was not measured in our study, as no such measurements were available due to its operational nature.

The strengths of our study include the relatively large number of patients and long follow-up in our cohort, data analysis in an operational setting, allowing inference about real world data in a clinical setting, and the improved active vital status finding coupled with CoDe, which allowed us to classify specific CODs for all patients followed.

The CoDe algorithm has been implemented in several observational cohorts around the world and has been demonstrated to be accurate in ascertaining both AIDS-related and non-AIDS-related causes of death in HIV-infected patients. ${ }^{32}$ The option to classify as NTR only those cases where TB was not mentioned in the CoDe review forms increased the specificity of this outcome, making it more reliable compared to considering TB as the underlying COD.

In conclusion, we found that TB was significantly associated with increased NTR CODs, with immunodeficiency-related CODs accounting for the great majority of NTR deaths. TB indicates rapid disease progression for both TB-related and NTR deaths, and should prompt immediate action, especially if CD4 and viral load monitoring is not available. TB also indicates long-term risk for NTR deaths, probably related to persistent immunodeficiency or incomplete immune recovery. Finally, our results reinforce the benefit of HAART and TB prophylaxis, representing another important reason to start ART and perform IPT according to established guidelines in Brazil.

\section{Acknowledgements}

The study was supported by the Fundação de Amparo à Pesquisa do Estado do Rio de Janeiro (FAPERJ), the Conselho Nacional de Desenvolvimento Científico e Tecnológico (CNPq), Programa Estratégico de Apoio à Pesquisa em Saúde (PAPES) and Fundação Oswaldo Cruz, Rio de Janeiro, RJ, Brazil.

Conflicts of interest: none declared. 


\section{References}

1 World Health Organization. Global tuberculosis report 2013. WHO/HTM/TB/2013.11. Geneva, Switzerland: WHO, 2013.

2 Ministério da Saúde. SINAN - Sistema de Informação de Agravos de Notificação. 2013. Brasilia, Brazil. http://dtr2004. saude.gov.br/sinanweb/index.php. Accessed September 2014.

3 Cavalcante S C, Soares E C, Pacheco A G, Chaisson R E, Durovni B. Community DOT for tuberculosis in a Brazilian favela: comparison with a clinic model. Int J Tuberc Lung Dis 2007; 11: 544-549.

4 Pacheco A G, Durovni B, Cavalcante S C, et al. AIDS-related tuberculosis in Rio de Janeiro, Brazil. PLOS ONE 2008; 3: e3132.

5 Ministério da Saúde. Boletim Epidemiológico - AIDS e DST. Ano II - no 1. Brasília 2013.

6 Paula A A, Schechter M, Tuboi S H, et al. Continuous increase of cardiovascular diseases, diabetes, and non-HIV related cancers as causes of death in HIV-infected individuals in Brazil: an analysis of nationwide data. PLOS ONE 2014; 9: e94636.

7 Durovni B, Saraceni V, Moulton L H, et al. Effect of improved tuberculosis screening and isoniazid preventive therapy on incidence of tuberculosis and death in patients with HIV in clinics in Rio de Janeiro, Brazil: a stepped wedge, clusterrandomised trial. Lancet Infect Dis 2013; 13: 852-858.

8 Saraceni V, Pacheco A G, Golub J E, et al. Physician adherence to guidelines for tuberculosis and HIV care in Rio de Janeiro, Brazil. Braz J Infect Dis. 2011; 15: 249-252.

9 Harries A D, Hargreaves N J, Gausi F, Kwanjana J H, Salaniponi F M. High early death rate in tuberculosis patients in Malawi. Int J Tuberc Lung Dis 2001; 5: 1000-1005.

10 Worodria W, Massinga-Loembe M, Mazakpwe D, et al. Incidence and predictors of mortality and the effect of tuberculosis immune reconstitution inflammatory syndrome in a cohort of TB/HIV patients commencing antiretroviral therapy. J Acquir Immune Defic Syndr 2011; 58: 32-37.

11 Podlekareva D N, Panteleev A M, Grint D, et al. Short- and long-term mortality and causes of death in HIV/tuberculosis patients in Europe. Eur Respir J 2014; 43: 166-177.

12 Cain K P, Anekthananon T, Burapat C, et al. Causes of death in HIV-infected persons who have tuberculosis, Thailand. Emerg Infect Dis 2009; 15: 258-264.

13 Castelnuovo B, Manabe Y C, Kiragga A, Kamya M, Easterbrook P, Kambugu A. Cause-specific mortality and the contribution of immune reconstitution inflammatory syndrome in the first 3 years after antiretroviral therapy initiation in an urban African cohort. Clin Infect Dis 2009; 49: 965-972.

14 Kantipong P, Murakami K, Moolphate S, Aung M N, Yamada N. Causes of mortality among tuberculosis and HIV co-infected patients in Chiang Rai, Northern Thailand. HIV AIDS (Auckl) 2012; 4: 159-168.

15 Pacheco A G, Tuboi S H, Faulhaber J C, Harrison L H, Schechter M. Increase in non-AIDS related conditions as causes of death among HIV-infected individuals in the HAART era in Brazil. PLoS ONE. 2008; 3: e1531.

16 Grinsztejn B, Luz P M, Pacheco A G, et al. Changing mortality profile among HIV-infected patients in Rio de Janeiro, Brazil: shifting from AIDS to non-AIDS related conditions in the HAART era. PLoS ONE 2013; 8: e59768.

17 Pacheco A G, Tuboi S H, May S B, et al. Temporal changes in causes of death among HIV-infected patients in the HAART era in Rio de Janeiro, Brazil. J Acquir Immune Defic Syndr 2009; 51: 624-630.

18 Gupta A, Wood R, Kaplan R, Bekker L G, Lawn S D. Prevalent and incident tuberculosis are independent risk factors for mortality among patients accessing antiretroviral therapy in South Africa. PLOS ONE 2013; 8: e55824.

19 Leung C C, Hui L, Lee R S, et al. Tuberculosis is associated with increased lung cancer mortality. Int J Tuberc Lung Dis 2013; 17: 687-692.

20 Grinsztejn B, Veloso V G, Friedman R K, et al. Early mortality and cause of deaths in patients using HAART in Brazil and the United States. AIDS 2009; 23: 2107-2114.

21 Pacheco A G, Saraceni V, Tuboi S H, et al. Validation of a hierarchical deterministic record-linkage algorithm using data from 2 different cohorts of human immunodeficiency virusinfected persons and mortality databases in Brazil. Am J Epidemiol 2008; 168: 1326-1332.

22 R: A language and environment for statistical computing. [computer program]. Version 3.0.1. Vienna, Austria: R Foundation for Statistical Computing, 2013.

23 Ministério da Saúde. Protocolo clínico e diretrizes terapêuticas para manejo da infecção pelo HIV em adultos. Brasília, Brazil: Departamento de DST, AIDS e Hepatites Virais, 2013. [Portuguese]

24 Loo V S, Diaz T, Gadelha A M, et al. Managing HIV-infected patients on antiretroviral therapy in Rio de Janeiro, Brazil: do providers follow national guidelines? AIDS Care 2004; 16: 834-840.

25 Samji H, Cescon A, Hogg R S, et al. Closing the gap: increases in life expectancy among treated HIV-positive individuals in the United States and Canada. PLOS ONE 2013; 8: e81355.

26 Greig J, Casas E C, O’Brien D P, Mills E J, Ford N. Association between older age and adverse outcomes on antiretroviral therapy: a cohort analysis of programme data from nine countries. AIDS 2012; 26 (Suppl 1): S31-S37.

27 Simard E P, Fransua M, Naishadham D, Jemal A. The influence of sex, race/ethnicity, and educational attainment on human immunodeficiency virus death rates among adults, 1993-2007. Arch Intern Med 2012; 172: 1591-1598.

28 Kanters S, Nansubuga M, Mwehire D, et al. Increased mortality among HIV-positive men on antiretroviral therapy: survival differences between sexes explained by late initiation in Uganda. HIV AIDS (Auckl) 2013; 5: 111-119.

29 Charalambous S, Grant A D, Innes C, et al. Association of isoniazid preventive therapy with lower early mortality in individuals on antiretroviral therapy in a workplace programme. AIDS 2010; 24 (Suppl 5): S5-S13.

30 Gupta-Wright A, Wood R, Bekker L G, Lawn S D. Temporal association between incident tuberculosis and poor virological outcomes in a South African antiretroviral treatment service. J Acquir Immune Defic Syndr 2013; 64: 261-270.

31 Siika A M, Yiannoutsos C T, Wools-Kaloustian K K, et al. Active tuberculosis is associated with worse clinical outcomes in HIV-infected African patients on antiretroviral therapy. PLOS ONE 2013; 8: e53022.

32 Kowalska J D, Friis-Moller N, Kirk O, et al. The coding causes of death in HIV (CoDe) Project: initial results and evaluation of methodology. Epidemiology 2011; 22: 516-523. 
CONTEXTE : Patients infectés par le virus de l'immunodéficience humaine (VIH) suivis dans une vaste cohorte à Rio de Janeiro, Brésil.

O B JECTIF : Evaluer l'association de la tuberculose (TB) et d'autres covariables avec les causes de décès (COD) non liées à la TB (NTR).

SCHÉ M A : Les patients âgés de $>18$ ans ont été suivis de 1997 à 2009, soit jusqu'à leur décès soit jusqu'au 31 décembre 2009. Les COD ont été établies grâce à un algorithme standardisé. Le diagnostic et la prophylaxie de la TB étaient conformes aux directives brésiliennes. Les modèles de Poisson ont servi à calculer les odds ratio ajustés (RRa).

RÉ SULTATS : Sur 2887 patients inclus, 761 avaient une TB $(26,4 \%)$. Le taux de décès NTR était deux fois plus élevé chez les patients atteints de TB (4/100 contre 2,09/ 100 années patient). La TB était associée aux décès NTR
(RRa 1,4 ; IC95\% 1,05-1,86; $P=0,01)$. Le HAART était protecteur vis-à-vis des NTR (RRa 0,46 ; IC95\% 0,34-0,61; $P<0,001)$. Parmi les patients qui n'avaient jamais eu de TB active, la prophylaxie constituait également une protection vis-à-vis des NTR (RRa 0,45; $P=0,04)$. L'augmentation du nombre de CD4 était très modérée tant pour les COD liés à la TB que pour celles non liés à la TB, par comparaison aux sujets qui ne sont pas décédés ( 0 contre 249 cellules ; $P<0,001$ ).

CONCLUSIONS : La TB était significativement associée à une augmentation des COD non liées à la TB, représentant à la fois une alerte de progression rapide de la maladie et un risque accru de mortalité à long terme, probablement reliée à une persistance de la déficience immunitaire ou à une restauration incomplète de l'immunité. Nos résultats renforcent le bénéfice du HAART et de la prophylaxie de la TB.
MARCO DE REFERENCIA: El seguimiento de una gran cohorte de pacientes con infección por el virus de la inmunodeficiencia humana (VIH) en Río de Janeiro en el Brasil.

OBJETIVO: Evaluar en pacientes infectados por el VIH la asociación de la tuberculosis (TB) y otras covariables con las causas de muerte (COD) no relacionadas con la TB (NTR).

MÉTODO: Los pacientes de $>18$ años de edad que comenzaron el seguimiento de la infección por el VIH se observaron de 1997 al 2009 hasta el 31 de diciembre del 2009 o su muerte si ocurría primero. Las COD se verificaron mediante un algoritmo normalizado. El diagnóstico y la profilaxis de la TB cumplían con las directrices del Brasil. Los cocientes ajustados de las tasas de incidencia ( $R R a$ ) se calcularon mediante modelos de Poisson.

RESULTA D O S: Se incluyeron en estudio 2887 pacientes, de los cuales 761 contrajeron la TB $(26,4 \%)$. Las tasas de mortalidad por COD NTR fueron dos veces más altas en los pacientes que contrajeron la TB (4/100 contra 2,09/100 años-persona). La TB exhibió una correlación estadística significativa con las muertes por causas diferentes de esta enfermedad (RRa 1,4; IC95\% 1,05$1,86 ; P=0,01)$. El tratamiento antirretrovírico de gran actividad (HAART) ejerció un efecto protector contra las muertes no relacionadas con la TB (RRa 0,46; IC95\% 0,34-0,61; $P<0,001)$. En los pacientes que nunca presentaron TB activa, también se observó un efecto protector de la profilaxis ( $\mathrm{RRa} 0,45 ; P=0,04)$. El aumento del recuento de linfocitos CD4 fue muy escaso en los casos cuya causa de muerte se relacionó con la TB y también cuando fue independiente de ella, al compararlos con los pacientes que no fallecieron (0 contra 249 células/ml; $P<0,001$ ).

CONCLUSIONES: La TB exhibió una asociación estadística significativa con las COD NTR en los pacientes infectados por el VIH y por consiguiente representa un signo de alerta de progresión rápida del síndrome de inmunodeficiencia adquirida y además un mayor riesgo de muerte a largo plazo. Es probable que esta asociación corresponda a la persistencia de la inmunodeficiencia o a una recuperación inmunitaria incompleta. Los resultados del presente estudio confirman la utilidad del HAART y de la profilaxis de la TB. 